\title{
Availability and Use of Vaccines against COVID-19 in Pregnancy
}

\author{
Saugat Koirala' ${ }^{1}$, Smriti Pant ${ }^{2}$, Binay Kumar Chaudhary ${ }^{3}$ \\ 'Department of Obstetrics and Gynecology, Haamro Sahayatri Hospital, Jadibuti, Kathmandu, Nepal \\ 2Department of Community Medicine, Maharajgunj Medical Campus, Maharajgunj, Kathmandu, Nepal \\ ${ }^{2}$ Department of General Surgery, Bhaktapur Hospital, Bhaktapur, Nepal
}

ABSTRACT

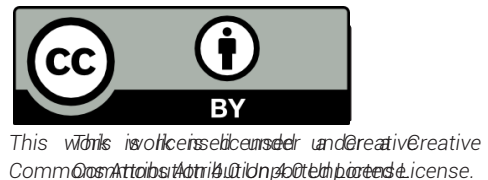

Pregnant women when infected with SARS-CoV-2 infection are more at risk of having severe outcomes including ICU admission, adverse cardiac and thromboembolic events and preterm delivery. Immunization in pregnancy has certain ethical dilemmas and vaccination seems to be challenging. Preliminary data regarding the use of mRNA based vaccines against this virus in pregnant women is promising. Recently, RCOG and WHO have widened the scope of use of vaccines among pregnant women against COVID-19. Similarly, ACOG has also given the go-ahead to the use of two mRNA based and one viral vector based vaccine in pregnant women. The scope of vaccination among pregnant and lactating women being realized in developed part of world is a promising prospect in prevention of COVID-19 infections. However, developing nations require attention from private stakeholders, health and social care organizations to ensure right of health for all.

\section{KEY WORDS}

Cornona Virus, COVID-19, Immunization, Pregnancy, Vaccination

\section{INTRODUCTION}

The SARS-CoV-2 (Corona Virus) infection was first identified in 2019 from a pneumonia patient in Wuhan, China and since then has rapidly spread all over the world [1]. Despite efforts in containment and quarantine measures, the infection rates along with morbidity and mortality due to this infection keep soaring [1]. With COVID-19 cases rising in significant proportion, the number of infected pregnant women of all gestational ages has increased rapidly [2].

Pregnant women are found to have severe outcomes with COVID-19 infection compared to non-pregnant women including greater rates of Intensive Care Unit admissions and preterm deliveries $[3,4]$. Acute respiratory distress syndrome, renal failure, adverse cardiac outcome, thromboembolic events are other complications in those gravid population who get infected with Corona Virus infection [5]. Physiological changes in pregnancy along with immunologic alterations add to the distress in the gravid population when they get infected with this virus $[6,7]$. Prevention of such infection with active immunization and prophylaxis is of as much importance if not more than the antiviral therapy [7]. Viral infection triggers hypoxia and inflammation in mothers along with cytokine storm with the release of interleukin-6 and TNF-alpha $[8,9]$. There have also been incidences of intrauterine transmission of this infection in the fetus $[8,9]$. The hypoxia and inflammation could have an association with adverse perinatal and neonatal outcomes [8]. Yet the issues of vertical transmission of COVID-19 infection and the potential of vaccine use in its prevention lags adequate research [10]. The aim of the article was to study about the availability of COVID-19 vaccine and its use in pregnancy and lactation. This article is one of the first ones to include the latest preliminary findings of the effects of vaccination in the pregnancy and lactation.

\section{METHOD}

For writing this Narrative Review article, Google, Google Scholar, Pub Med and online news portals were searched by using various combination of the following terminologies: "COVID-19", "Corona Virus", "SARS-CoV-2 ", "Pregnancy", "Lactation", "Vaccine", "Vaccination", "Immunization", "Pfizer", "Moderna", "Janssen", "Oxford", "AstraZeneca", "Newborn", "CDC", "FDA", "ACOG", "RCOG", "WHO", "Findings" and "Outcomes". We screened all the articles that we found from the search, with the aim of including articles that had information about different types of vaccines against COVID-19 and their use in pregnancy. Next, we acquired the full text of the potential articles and used the articles that met our criteria for writing the review. The duration of writing the article was two months.

\section{*Corresponding Author}

Dr. Saugat Koirala, Department of Obstetrics and Gynecology, Haamro Sahayatri Hospital, Jadibuti, Kathmandu, Nepal | Email: saugatkoirala.sk@gmail.com 


\section{VACCINATION IN PREGNANCY}

Immunization is a known mode to check the spread of vaccine-preventable infectious diseases among pregnant ladies and their newborn [11]. Few inactivated vaccines are available for routine use in pregnancy [11, 12]. However, because of risks of abortion, premature delivery, congenital anomaly and fetal morbidity and mortality; several live attenuated vaccines and other inactivated vaccines are only available for selective use $[11,12]$. Routine immunization is administered to all the pregnant women for the prevention against tetanus, diphtheria and pertussis [12, 13]. Apart from those, there are vaccines offered only to the women at high risk of exposure to hepatitis A and B, pneumococcal, meningococcal, typhoid, polio infections while only postexposure prophylaxis are given for rabies and anthrax [12, 13].

\section{VACCINE AGAINST COVID-19 IN PREGNANCY AND LACTATION}

Only few SARS-CoV-2 vaccines are available with phase-III results, for example mRNA, viral vector, recombinant antigen and inactivated virus, with high protection rates against this infection [14]. The US Food and Drug Administration (FDA) and the European Medicines Agency (EMA) have approved only three COVID-19 vaccines for emergency use in which mRNA based are Moderna, BioNTech (Pfizer) while adenoviral vector-based is Ad26.CoV2.S (Janssen) [14-16]. Oxford- AstraZeneca (AZD1222) is a viral vector vaccine which has been approved by EMA and has been used in the citizens of the U.K. [14-16].

Early findings of safety of mRNA Covid-19 vaccine among 35,691 pregnant women in the United States, who had been vaccinated from 14th of December 2020 to 28th of February 2020 are available [17]. This study showed no noticeable issues regarding harm to the health of mother or the fetus/ newborn because of immunization with mRNA COVID-19 vaccines: Pfizer-BioNTech and Moderna [17]. Among the 827 women who had completed their pregnancy after receiving vaccination, the most common adverse event was spontaneous abortion (12.6\%), which was no higher than the normal population who undergo pregnancy [17]. Other outcomes like stillbirth, preterm birth, small for gestational age and neonatal age were also noted, all of which had occurrence no greater than the general population [17].

In Poland, a retrospective study among 150 pregnant women vaccinated with two doses of BNT162b2 mRNA COVID-19 vaccine had suggested that maternal vaccination could confer newborn safety via trans-placental transference of antibodies [18]. While a case report on a woman who had received BNT162b2 mRNA vaccine had similar result, where trans-placental antibodies for SARS-CoV-2 were found on the newborn [19]. A New York based study done between January and March 2021 in 122 pregnant women who received mRNA vaccine also showed that the transference of trans-placental antibody could be expected in the newborn and that too as soon as 16 days from the administration of the first dose [20].

Another cohort study from Israel had enrolled pregnant women, breastfeeding mother and non-pregnant women between 18 and 45 years age group, from December 2020 to March 2021 for receiving mRNA COVID-19 vaccine (either Moderna or Pfizer-BioNTech) [21]. Among those participants, there were 30 pregnant and 16 lactating women who had received immunization as proposed with no severe complications on pregnancy or the baby [21]. According to this study, the used mRNA vaccines induced protective immune responses against SARS-CoV-2 among all the study population [21].

\section{GUIDELINES AND RECOMMENDATION ON COVID-19 VACCINES IN PREGNANCY AND LACTATION}

Despite limited data available about vaccination in pregnant women, Center for Disease Control, USA and FDA in the United States have recently approved for the use of Johnson \& Johnson's Janssen COVID-19 vaccine in pregnancy and lactation [22]. For general population planning to conceive, WHO and CDC have approved the mRNA vaccines, while for pregnant women without comorbidity only Pfizer has proposed for administration of its mRNA vaccine [23]. CDC, EMA, JCVI and Pfizer, however, recommends SARS-CoV-2 vaccination with $\mathrm{MRNA}$ vaccination in lactating women [23].

Royal College of Obstetrics and Gynecology (RCOG) has recently published an updated list of the groups of pregnant women who could be offered the Pfizer or Moderna COVID-19 vaccine [24]. This includes pregnant women having higher chances of getting severe COVID-19 infection, health and social care workers with increased risk of catching this infection [24]. Also, women with underlying health conditions, gestational diabetes or women with a BMI of over $40 \mathrm{~kg} / \mathrm{m} 2$ are eligible for vaccination against Corona Virus [24]. American College of Obstetrics and Gynecology (ACOG) has also recommended the pregnant and lactating women to have access to COVID-19 vaccines, but this includes only afore mentioned vaccines approved by US FDA for emergency use, which includes those manufactured by Moderna, Jannsen and Pfizer (Table 1) [25].

Concerns regarding mild side effects of the COVID-19 vaccine ranges from injection site soreness, lethargy, fever, chills, joint and muscle pain [24, 25]. In patients immunized with AstraZeneca vaccine and Janssen vaccine against COVID-19, serious cases of thrombosis with thrombocytopenia syndrome (TTS) have been reported in general population $[24,25]$. Thus, it is logical to say that 
Moderna and Pfizer manufactured mRNA vaccines against SARS-CoV-2 for now should be available to pregnant and breastfeeding women throughout the world.

There is a pregnancy exposure registry for Moderna, AstraZeneca and Janssen Covid-19 vaccines which are in the process of clinical trial registration for immunization during pregnancy $[26,27]$. In most parts of the world, pregnant women have been left off of the clinical trials because of the concerns regarding safety of vaccine in pregnant and lactating mothers and their fetuses and lack of a common consensus of the authorities [28].

\section{INEQUITY IN DISTRIBUTION AND CHALLENGES OF ACCEPTANCE}

We should also note that maternal health care facilities, including provision of immunization service, have suffered during this COVID-19 pandemic, especially in developing countries [29]. Many developing nations have to depend on other developed countries for vaccines [30]. Low and middle-income countries have suffered from a collapse of healthcare system in this deadly pandemic and have been deprived of vaccines because of various challenges in receival, distribution and administration of vaccine. The spread of COVID-19 infections among pregnant women has made it even worse [30, 31]. Even the frontline pregnant workers in many parts of world are yet to be immunized against Corona Virus infection [32]. It is an alarming issue of whether the mutations in the SARS-CoV-2 will lead to lesser effectiveness of available vaccines to the newer variants [33].

Another challenge lies in appropriate and needful counseling in pregnant women with clarity regarding the risks of COVID-19 in pregnancy, available data of the safety and effectiveness of the vaccine and scope of future research [14]. With this comes the issue of acceptance of vaccine among pregnant and lactating women against this infection. Ethical issues of subjecting those "vulnerable" groups to experimentation has come against large-scale trial of the safe and efficacious vaccine on pregnant and lactating women [14, 34]. In a survey conducted in 662 pregnant women in New York, nearly half of the women were concerned that vaccination against Coronavirus in pregnancy could lead to birth defects and would have longstanding health effects in the baby [35]. In another online, cross-sectional survey, 2743 out of 5282 pregnant women had responded positively towards vaccine acceptance which was performed among 16 nations to assess the COVID-19 vaccine acceptance [36].

This pandemic has cautioned everyone not to take infectious disease lightly and stressed out the role of immunization either in pregnant or non-pregnant population [37]. So, the developed countries, private stakeholders and other organizations like UNICEF, GAVI, WHO and other organizations should ensure fair access to vaccination against COVID-19 worldwide [38].

\section{CONCLUSION}

Stakeholders and large health care organizations should ensure rights of good health in all individuals. Considering many pregnant and lactating women experiencing morbidity and mortality because of COVID-19, prevention of infection with immunization in this era is of particular importance. The immunogenicity of mRNA based vaccines against COVID-19 along with placental transference of antibodies would offer protection to the neonate. In general population, those mRNA based vaccine have been found to be safe and efficacious with fewer adverse effect profile. Health care authorities all over the world should consider the recent recommendation by ACOG and RCOG towards use of COVID vaccine in pregnancy and breastfeeding. They should come up with the solutions to ensure pregnant and

lactating women globally get vaccinated with mRNA based vaccines.

TABLE 1 Types of Vaccines and Recommendations for use in Pregnancy and Breastfeeding [14, 23-25]

\begin{tabular}{|c|c|c|c|c|c|c|c|}
\hline $\begin{array}{c}\text { Type of SARS-CoV-2 } \\
\text { Vaccine }\end{array}$ & Manufacturer & Technology & CDC & WHO & $\begin{array}{l}\text { Breast } \\
\text { feeding }\end{array}$ & ACOG & RCOG \\
\hline mRNA-1273 & Pfizer, BioNTech & mRNA & $\begin{array}{l}\text { In pregnancy with } \\
\text { comorbidities }\end{array}$ & $\begin{array}{l}\text { MBC in women } \\
\text { with risk of } \\
\text { exposure }\end{array}$ & $\mathrm{R}$ & R & $\begin{array}{l}\mathrm{R} \text { in high risk } \\
\text { cases }\end{array}$ \\
\hline BNT162b2 & $\begin{array}{l}\text { Moderna } \\
\text { Therapeutics }\end{array}$ & mRNA & $\begin{array}{l}\text { In pregnancy with } \\
\text { comorbidities }\end{array}$ & $\begin{array}{l}\mathrm{MBC} \text { in women } \\
\text { with risk of } \\
\text { exposure }\end{array}$ & $\begin{array}{l}\mathrm{MBC} \\
(\mathrm{WHO})\end{array}$ & $\mathrm{R}$ & $\begin{array}{l}\mathrm{R} \text { in high risk } \\
\text { cases }\end{array}$ \\
\hline AZD1222 & Oxford- AstraZeneca & Viral vector & - & - & - & - & - \\
\hline Ad26.COV2.S & $\begin{array}{l}\text { Janssen } \\
\text { Pharmaceutica }\end{array}$ & Viral vector & $\mathrm{R}$ & - & $\begin{array}{l}\mathrm{R} \\
\text { (CDC) }\end{array}$ & $\mathrm{R}$ & - \\
\hline
\end{tabular}

$R=$ Recommended, $M B C=$ May be Considered, high risk cases = includes those having high risk of catching infection, high BMI, GDM, health and social care workers 


\section{Author Contributions}

SK conceptualized the idea, formulated the methodology, wrote the original draft, reviewed and edited the article. SP contributed to formulation of the methodology, reviewed and edited the article. BKC also reviewed and edited the article.

\section{Financial Support}

No funding was obtained for writing the article.

\section{Conflict of Interest}

Authors declare no conflict of interest.

\section{REFERENCES}

1. Sohrabi C, Alsafi Z, O'Neill N, Khan M, Kerwan A, Al-Jabir A, et al. World Health Organization declares global emergency: A review of the 2019 novel coronavirus (COVID-19). International journal of surgery. 2020;76:71-6.

2. Balakrishnan A, May-Han L, Heng TC, Lin SL, Edward YB, Chien LD, et al. Care of the pregnant woman with covid-19 in labor and delivery: anesthesia, emergency cesarean delivery, differential diagnosis in the acutely ill parturient, care of the newborn, and protection of the healthcare personnel. https:// wwwncbinlmnihgov/pmc/articles/PMC7151436/pdf/mainpdf. 2020.

3. Allotey J, Stallings E, Bonet M, Yap M, Chatterjee S, Kew T, et al. Clinical manifestations, risk factors, and maternal and perinatal outcomes of coronavirus disease 2019 in pregnancy: living systematic review and meta-analysis. bmj. 2020;370.

4. Zambrano LD, Ellington S, Strid P, Galang RR, Oduyebo T, Tong $V T$, et al. Update: characteristics of symptomatic women of reproductive age with laboratory-confirmed SARS-CoV-2 infection by pregnancy status-United States, January 22October 3, 2020. Morbidity and Mortality Weekly Report. 2020;69(44):1641.

5. Ko JY, DeSisto CL, Simeone RM, Ellington S, Galang RR, Oduyebo T, et al. Adverse pregnancy outcomes, maternal complications, and severe illness among U.S. delivery hospitalizations with and without a COVID-19 diagnosis. Clin Infect Dis. 2021.

6. Vlachodimitropoulou Koumoutsea E, Vivanti AJ, Shehata N, Benachi A, Le Gouez A, Desconclois C, et al. COVID 19 and acute coagulopathy in pregnancy. Journal of Thrombosis and Haemostasis. 2020;18(7):1648-52.

7. Ramsey PS, Ramin KD. Pneumonia in pregnancy. Obstetrics and gynecology clinics of North America. 2001;28(3):553-69.

8. Wong MCS, Wong ELY, Huang J, Cheung AWL, Law K, Chong MKC, et al. Acceptance of the COVID-19 vaccine based on the health belief model: A population-based survey in Hong Kong. Vaccine. 2021;39(7):1148-56.

9. Warden A, Caldera K. The essential role of a physiatrist in recommending a COVID-19 vaccine. PM R. 2021.
10. Joma M, Fovet CM, Seddiki N, Gressens P, Laforge M. COVID-19 and Pregnancy: Vertical Transmission and Inflammation Impact on Newborns. Vaccines (Basel). 2021;9(4).

11. Keller-Stanislawski B, Englund JA, Kang G, Mangtani P, Neuzil $\mathrm{K}$, Nohynek $\mathrm{H}$, et al. Safety of immunization during pregnancy: a review of the evidence of selected inactivated and live attenuated vaccines. Vaccine. 2014;32(52):7057-64.

12. Riccardo F, Réal A, Voena C, Chiarle R, Cavallo F, Barutello G. Maternal immunization: new perspectives on its application against non-infectious related diseases in newborns. Vaccines. 2017;5(3):20.

13. Arora M, Lakshmi R. Maternal vaccines-safety in pregnancy. Best Practice \& Research Clinical Obstetrics \& Gynaecology. 2021.

14. Kalafat E, O'Brien P, Heath PT, Le Doare K, von Dadelszen P, Magee $L$, et al. Benefits and potential harms of COVID-19 vaccination during pregnancy: evidence summary for patient counseling. Ultrasound Obstet Gynecol. 2021;57(5):681-6.

15. Voysey M, Clemens SAC, Madhi SA, Weckx LY, Folegatti PM, Aley PK, et al. Safety and efficacy of the ChAdOx1 nCoV-19 vaccine (AZD1222) against SARS-CoV-2: an interim analysis of four randomised controlled trials in Brazil, South Africa, and the UK. The Lancet. 2021;397(10269):99-111.

16. Polack FP, Thomas SJ, Kitchin N, Absalon J, Gurtman A, Lockhart S, et al. Safety and efficacy of the BNT162b2 mRNA Covid-19 vaccine. New England Journal of Medicine. 2020;383(27):2603-15.

17. Shimabukuro TT, Kim SY, Myers TR, Moro PL, Oduyebo T, Panagiotakopoulos $L$, et al. Preliminary Findings of mRNA Covid-19 Vaccine Safety in Pregnant Persons. N Engl J Med. 2021.

18. Zdanowski W, Waśniewski T. High SARS-CoV-2 protein S antibody titers in cord blood after COVID-19 vaccination during pregnancy: preliminary results. 2021.

19. Gill L, Jones CW. Severe acute respiratory syndrome coronavirus 2 (SARS-CoV-2) antibodies in neonatal cord blood after vaccination in pregnancy. Obstetrics \& Gynecology. 2021;137(5):894-6.

20. Prabhu M, Murphy EA, Sukhu AC, Yee J, Singh S, Eng D, et al. Antibody Response to Coronavirus Disease 2019 (COVID-19) Messenger RNA Vaccination in Pregnant Women and Transplacental Passage Into Cord Blood. Obstetrics \& Gynecology. 2021:10.1097.

21. Collier A, McMahan K, Yu J, Tostanoski LH, Aguayo R, Ansel J, et al. Immunogenicity of COVID-19 mRNA Vaccines in Pregnant and Lactating Women. JAMA. 2021.

22. Prevention CfDCa. COVID-19 Vaccines While Pregnant or Breastfeeding 2021 [Available from: https://www.cdc. gov/coronavirus/2019-ncov/vaccines/recommendations/ pregnancy.html\#.

23. Ory S, Veiga A, Horton M, Gianaroli L. Joint IFFS/ESHRE statement on COVID-19 vaccination for pregnant women and 
those considering pregnancy. Human Reproduction Open. 2021;2021(2):hoab016.

24. (RCOG) RCoOaG. Information sheet and decision aid: Updated 14 May 2021. 2021:6.

25. Turrentine M, Carroll S. Vaccinating Pregnant and Lactating Patients Against COVID-19. 2021.

26. COVID-19 Vaccines International Pregnancy Exposure Registry (C-VIPER) [Internet]. 2021. Available from: https://clinicaltrials. gov/ct2/show/NCT04705116.

27. Canada PHAo. Recommendations on the use of COVID-19 vaccines 2021. Available from: https://www.canada.ca/en/ public-health/services/immunization/national-advisorycommittee-on-immunization-naci/recommendations-usecovid-19-vaccines.html\#apg

28. Heath PT, Le Doare K, Khalil A. Inclusion of pregnant women in COVID-19 vaccine development. The Lancet Infectious Diseases. 2020;20(9):1007-8.

29. Pant S, Koirala S, Subedi M. Access to maternal health services during COVID-19. Europasian Journal of Medical Sciences. 2020;2(2):48-52.

30. Sheikh AB, Pal S, Javed N, Shekhar R. COVID-19 Vaccination in Developing Nations: Challenges and Opportunities for Innovation. Infectious Disease Reports. 2021;13(2):429-36.

31. Wastnedge EA, Reynolds RM, van Boeckel SR, Stock SJ, Denison FC, Maybin JA, et al. Pregnancy and COVID-19. Physiological reviews. 2021;101(1):303-18.

32. Jaffe EF, Karron RA, Krubiner CB, Wonodi CB, Beigi RH, Sheffield JS, et al. Global equity in protection of pregnant frontline workers. Wellcome Open Research. 2021;6(66):66.

33. Williams $H$, Hutchinson $D$, Stone $H$. Watching Brief: The evolution and impact of COVID-19 variants B. 1.1. 7, B. 1.351, P. 1 and B. 1.617. Global Biosecurity. 2021;3(1).

34. Farrell R, Michie M, Pope R. Pregnant Women in Trials of Covid-19: A Critical Time to Consider Ethical Frameworks of Inclusion in Clinical Trials. Ethics Hum Res. 2020;42(4):17-23.

35. Levy AT, Singh S, Riley LE, Prabhu M. Acceptance of COVID-19 vaccination in pregnancy: A survey study. Am J Obstet Gynecol MFM. 2021:100399.

36. Skjefte M, Ngirbabul M, Akeju O, Escudero D, Hernandez-Diaz S, Wyszynski DF, et al. COVID-19 vaccine acceptance among pregnant women and mothers of young children: results of a survey in 16 countries. Eur J Epidemiol. 2021;36(2):197-211.

37. Saxena S, Skirrow H, Bedford H. Routine vaccination during covid-19 pandemic response. BMJ. 2020;369:m2392.

38. Acharya KP, Ghimire TR, Subramanya SH. Access to and equitable distribution of COVID-19 vaccine in low-income countries. npj Vaccines. 2021;6(1):1-3. 